\title{
Jehovah's Witnesses' refusal of blood: obedience to scripture and religious conscience
}

\author{
Donald T Ridley Watch Tower Bible and Tract Society, Patterson, NY, USA
}

\begin{abstract}
fehovah's Witnesses are students of the Bible. They refuse transfusions out of obedience to the scriptural directive to abstain and keep from blood. $\mathrm{Dr}$ Muramoto disagrees with the Witnesses' religious beliefs in this regard. Despite this basic disagreement over the meaning of Biblical texts, Muramoto flouts the religious basis for the Witnesses' position. His proposed policy change about accepting transfusions in private not only conflicts with the Witnesses' fundamental beliefs but it promotes hypocrisy. In addition, Muramoto's arguments about pressure to conform and coerced disclosure of private information misrepresent the beliefs and practices of fehovah's Witnesses and ignore the element of individual conscience. In short, Muramoto resorts to distortion and uncorroborated assertions in his effort to portray a matter of religious faith as a matter of medical ethical debate.
\end{abstract}

(Fournal of Medical Ethics 1999;25:469-472)

Keywords: Religion; Jehovah's Witnesses; blood transfusion

\section{Introduction}

Since the days of Jesus' apostles in the first century, Christians have been directed to "abstain" and "keep" from blood. ' Jehovah's Witnesses, as students of the Bible and imitators of those first century Christians, believe this scriptural directive applies to transfused blood and its major components. Although Dr Muramoto asserts that his proposal would entail only a "minimal change in policy", in fact it would require frank disregard of a number of important Bible teachings. Muramoto's proposal emanates from his basic disagreement with the Witnesses' view of the scriptural directive to abstain and keep from blood. Muramoto certainly is free to construe the scriptures as he pleases and to maintain that his views are the correct ones. However, it is not readily apparent how exegetical differences between Muramoto and Jehovah's Witnesses advance medical ethical discourse.
At bottom, Muramoto's proposal rests on the same unsubstantiated assertions presented in his previous papers. Muramoto persists in his unproven arguments 1) that Jehovah's Witnesses refuse blood for reasons other than religious faith, and 2) that the possible disapprobation of one's peers precludes responsible, independent decision making. He now continues in this mode by presenting a proposal that misrepresents Jehovah's Witnesses' practices regarding confidentiality. Thus, his call for a "change in policy" relies on misrepresentations based on his previous uncorroborated assertions. Muramoto's overall effort to subject a decision motivated by religious faith to bioethical analysis belittles religious faith and perverts the role of medical ethics.

Jehovah's Witnesses and obedience to God Jehovah's Witnesses believe that the Bible is the divinely inspired word of God. ${ }^{2}$ They therefore devote themselves to its study and strive to apply its counsel in all aspects of their lives. ${ }^{3}$ Accordingly, the Witnesses accept Jesus' statement that the greatest commandment is to "love Jehovah your God with your whole heart and with your whole soul and with your whole mind and with your whole strength". "The Witnesses also accept the apostle John's subsequent statement that, among other things, "the love of God means that we observe his commandments". Jesus' example of obeying his father's commandments is the model Jehovah's Witnesses seek to imitate. ${ }^{6}$ Thus, like Jesus, the Witnesses endeavour to think the way God thinks, to live their lives according to his values and standards. ${ }^{7}$

Muramoto says his proposed policy requires no "fundamental doctrinal changes" in the Witnesses' beliefs about the scriptural command to abstain from blood. Quite to the contrary, his proposal would encourage Witnesses to act privately in a manner they publicly declare to be wrong. Muramoto's proposal therefore trivialises the personal religious convictions of Jehovah's Witnesses by suggesting they ignore their belief that the love 
of God means that they observe his commandments. As Brown-Saltzman aptly observes: "it may be that it is when we fail to interweave the spiritual into ethical decisions in healthcare that we create the greatest problems". ${ }^{8}$

Jehovah's Witnesses believe that God sees everything we do regardless of whether other humans are aware of our actions. ${ }^{9}$ Hence, the Witnesses do not believe that if no one knows what they do in private, their relationship with God is not affected. A proposal like Muramoto's, which encourages hypocritical disregard of fundamental Bible teachings, would not be given a second thought by Jehovah's Witnesses.

\section{Freedom of choice}

Aside from the false assertion that no change in doctrine would be required by his proposal, Muramoto says the Witnesses do not refuse blood voluntarily out of obedience to scripture. According to Muramoto, the Witnesses are victims of organisational domination and coercion and reluctantly refuse blood out of fear of reprisal. Muramoto says that individual Witnesses are so influenced and controlled by the organisation's views on blood that their refusal is not truly autonomous. Muramoto goes so far as to say that the Witnesses are the victims of "psychological manipulation", although he cites no studies from the psychological literature or any other credible source to support this claim. ${ }^{10}$ This is hardly surprising. In 1987, the American Psychological Association determined that theories of coercive manipulation or "mind control" as applied to religious movements lacked any scientific foundation and should not be presented as scientific. ${ }^{11}$ Since that time "mind control" theories have been consistently rejected by scholars and courts of law in the United States and elsewhere. ${ }^{12}$ It is unfortunate that Muramoto has found a forum in three issues of this journal to advance arguments that rest on a theory roundly debunked by the scientific community over a decade ago.

To be sure, honouring patient values in health care decision making and respecting patient self-determination are of the utmost importance. But Muramoto seems to think that any outside influence with which a doctor disagrees destroys patient autonomy. There can be little doubt that all manner of outside influences affect patients' health care decisions - things they hear on TV or radio; things they read in newspapers and magazines; discussions they have with neighbours and friends; their own prior health care experiences. The question is not whether patients' decisions are influenced by outside sources; they most certainly are, and by more than anyone can

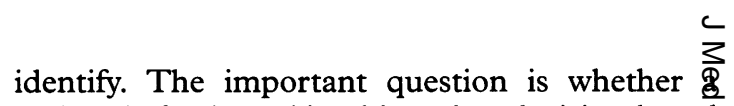
patient is freely making his or her decision based on the factors or values he or she personally deem to be the most important. ${ }^{13}$

Muramoto suggests that after a person hat studied the Bible with Jehovah's Witnesses for months or perhaps years and then decides to be baptised and become one of Jehovah's Witnesse there is no way he can later change his mind an $\mathrm{g}$ leave the faith. Muramoto's authority for this argument is dubious at best. The fact is, those whô wish to leave the religion or choose to become inactive non-participants readily do so. ${ }^{14}{ }^{16} \mathrm{De}$ spite this indisputable fact, Muramoto repeatedI refers to the "enormous" pressure to conform that, according to Muramoto, results from thi Witnesses' Bible-based practice of disfellowship ping. As Muramoto describes things, disfellowi shipping requires shunning and severance o $\Phi$ personal ties with family members - another mis representation of the facts.

Disfellowshipping is a very serious matter. The apostle Paul wrote that Christians should "quit mixing in company" with persons wh unrepentantly reject certain scriptural standards. .9? This is strong counsel, but Jehovah's Witnesse $\overrightarrow{8}$ obey it. However, contrary to Muramoto's asgexo tions, when a family member is disfellowshipped personal ties and non-spiritual association are terminated. The very passage from the $1 \overline{9} 8 \frac{7}{9}$ Watchtower that Muramoto quotes in his firgt paper disproves his point. That passage shows the it is spiritual association that is terminated:

"A disfellowshiped person has been spiritually co off from the congregation; the former spiritual tie have been completely severed. This is true even

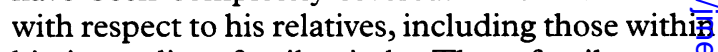
his immediate family circle. Thus, family mems bers - while acknowledging family ties - will nב. longer have any spiritual fellowship with him. ${ }^{19}$

That same Watchtower article explained that mar tal ties would not be severed if one's mate were to be disfellowshiped: "similarly, if a relative, such a parent, son or daughter, is disfellowshipped ... blood and family ties remain. ... If a minor child 5 disfellowshipped, the parents will still care for his physical needs and provide moral training and discipline." ${ }^{\prime 8}$ In short, "family ties continue. ... man who is disfellowshiped ... may still live at home with his Christian wife and faithful childrè ... ; since his being disfellowshiped does not end their blood ties or marriage relationship, normat family affections and dealings can continue."20

Disfellowshipping therefore involves a rescie sion of one's membership in the faith and a breals ing off of spiritual fellowship with members of the 
religious community. How this amounts to some form of socially unacceptable "coercion" remains unclear. Although Malyon already has responded to Muramoto's argument that no one does anything for ethical reasons, ${ }^{21}$ Muramoto continues with his theory that people never act on the basis of personal integrity and principle - religious or otherwise - but only claim to do so; in Muramoto's view people are motivated (coerced) by peer pressure and fear of discipline only. Muramoto evidently thinks that no member of any group or community is truly autonomous if the group or community has authority to discipline non-compliant members.

\section{Freedom of association}

Muramoto essentially advances the anarchic notion that, after freely choosing to join an organisation because they have come to share or identify themselves with the organisation's basic values or objectives and after agreeing to abide by its rules and procedures, individuals should nevertheless be free to abandon those values and objectives and reject the organisation's rules and procedures but still insist that the organisation accept them as full and active members in good standing. This argument is patently absurd. As the Encyclopedia of Religion simply explains: "any community claims the right to protect itself against nonconforming members who may threaten the common welfare. In a religious setting this right has often been reinforced by the belief that the sanction affects one's standing before God."22

Especially when it comes to a Bible-based religious community, Muramoto's suggestion that each individual should be free to disregard the community's scriptural teachings and standards yet remain a member of the community is preposterous. Of course individuals are free to do as they please, but they cannot demand that their community forsake its values and rules to satisfy the predilections of each member. Those who share Muramoto's views on blood may form their own religious communities, accept transfusions without reserve, and encourage members to do whatever they wish "in private". Jehovah's Witnesses certainly will not stop them. But $\mathrm{Mu}-$ ramoto cannot seriously insist that the Witnesses must modify or abandon their understanding of the scriptures to accommodate all differing or contrary viewpoints.

Muramoto's reference to Mill's statement about no society being completely free if its government does not allow citizens to pursue their own good without depriving or impeding others from doing the same is misapplied outside the context of civil government. Mill's point was that a government that restricts or prohibits the free exchange of ideas and freedom of action or that does not allow like-minded individuals to associate together and promulgate their views does not truly protect individual liberty. Jehovah's Witnesses have no quarrel with Mill's argument. Muramoto and those who share his views are completely free to promote their ideas individually or in whatever associational configurations they choose. But Jehovah's Witnesses are free to do the same. Freedom in this sense does not mean that everyone has the prerogative to alter the precepts and reorder the structure of groups or organisations whose ideas and practices they disagree with. The putting into practice of Muramoto's nonsensical concept of "freedom" would result in the utter breakdown of ordered society.

\section{Respect for privacy}

Muramoto says that the elders in congregations of Jehovah's Witnesses, hospital liaison committee members, and others intrusively monitor and pry into Witness patients' medical treatment decisions. He claims there is overwhelming peer pressure on Witness patients to divulge details of their hospital care. Not surprisingly, Muramoto provides no authority for these statements. The fact is, neither elders nor committee members have ever been instructed or encouraged to probe into the health care decisions of Witness patients. To the contrary, committee members have been explicitly instructed not to involve themselves in Witness patient hospitalisations unless their assistance is specifically requested by the patient. Thus, Muramoto's call for a withdrawal of such meddling tactics is meaningless; there are no such tactics to withdraw.

What about Witness patients who admit to their congregation elders that they accepted a blood transfusion? Muramoto says the organisation should teach individual Witnesses to keep their private medical affairs to themselves because, according to Muramoto, the only reason they disclose such information is organisational pressure and coercion. In Muramoto's view of things, Witness patients should feel free to violate the Bible's command to abstain from blood without compunction or remorse. Presumably Muramoto's view also would allow Witnesses freely to engage in adultery or drunken behaviour, notwithstanding the Bible's condemnation of these practices, provided these activities were kept private.

Muramoto's argument in this regard completely ignores the element of conscience and, as mentioned earlier, the fundamental Bible teaching that the love of God means obeying his commandments, not disobeying them and hiding one's 
disobedience from others. The Bible contains numerous examples of servants of God who erred and later confessed their sins to God and to fellow believers. ${ }^{23}$ As the scriptures make abundantly clear, Christians are encouraged voluntarily to confess their sins and to seek assistance from their spiritual elders. ${ }^{24}$ Thus, whether a Witness confesses wrongdoing is his personal decision; those who choose to do so, do so out of love for Jehovah and respect for his standards. Muramoto's proposal to educate Jehovah's Witnesses about their privacy rights is therefore inapposite because it has nothing to do with the Witnesses' sincere, conscientious desire to obey Jehovah's commands.

\section{Conclusion}

Muramoto's disdain for the religious convictions of Jehovah's Witnesses is palpable. On the strength of nothing more than unsupported assertions, Muramoto implies that because he does not agree with the Witnesses' scripturally based beliefs, no one else could possibly embrace such beliefs without being the victim of either coercion or brainwashing. As a result of these distorted views, Muramoto's proposals to rein in allegedly intrusive elders and to educate individual Witnesses about their privacy rights address nonexistent problems. Witness elders and hospital liaison committee members are not commissioned, explicitly or otherwise, to pry into the private affairs of individual Witnesses. However, if individuals conscientiously volunteer information of unscriptural conduct, the elders will perform their Christian duty to provide pastoral assistance and otherwise deal with the situation. Similarly, individual Witnesses are as informed about patient confidentiality as the general public. If doctors wish specifically to discuss this subject with their Witness patients, that is their business. But such information is irrelevant to the Witnesses' relationship with their God.

Muramoto's previous papers and his current proposal amount to an attack on Jehovah's Witnesses for exercising a right exercised by public and private groups of all kinds, the right to dismiss members who, after voluntarily joining the group, later reject or refuse to abide by the group's values. Fanciful theories about the loss of free will resulting from the possibility of such dismissal do not override a simple fact of which Jehovah's Witnesses are well aware: regardless of their associates, people do what they want. Indeed, if Muramoto were to begin espousing the reasonableness of the Witnesses' refusal of blood, the group of Witness opposers with whom he now associates undoubtedly would abandon him in short order. I have no doubt, however, that Muramoto possesses the autonomy and free with to change his mind if he chooses, despite an pressure he might feel from this group.

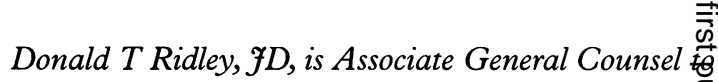
the Watch Tower Bible and Tract Society. Address coE respondence to: Legal Department, 100 Watchtower Drive, Patterson, NY 12563-9204, USA. E-ma离 dridley@wtbts.org

\section{References and notes}

1 The Bible. Acts 15: 28, 29; 21:25. Although Dr Muramota refers to the amicable agreement (friendly settlement) reache by Jehovah's Witnesses in Bulgaria and the Bulgariam government before the European Commission of Human Rights in March 1998, the language he quotes appears to conis from a press release issued by the European Commission. TKe amicable agreement itself does not contain the language quotes. In any event, more important is the language of this organisational charter actually filed by the Witnesses Bulgaria and registered (ie, officially accepted) by the Bulgarian government in October 1998. Regarding medical care, artict $7(1)$ of the charter states: "The Denomination of Jehovah's Witnesses in Bulgaria does not exercise any control over the free will of believers but allows them to exercise their conscien consistent with godly principles nor does the Denomination arbitrarily apply sanctions in connection with medical care th Jehovah's Witnesses conscientiously seek for themselves an their children. The Denomination adheres to the loving and righteous principles of God's Word in this aspect of Christian life." Thus, as Malyon already has explained and as Muramo reluctantly now seems to accept, there has been no chan is in the Witnesses' beliefs about abstaining and keeping from btoo

2 The Bible. 2 Timothy 3:15, 16; 2 Peter 1:21.

3 The Bible. Psalm 1:1,2; Proverbs 3:5, 6; 1 Timothy 4:15.

4 The Bible. Mark 12:30; Matthew 22:37.

5 The Bible. 1 John 5:3.

6 The Bible.John 13:15; 1 Peter 2:21.

7 The Bible. John 5:30; 8:28.

8 Brown-Saltzman KA. Responding to the spiritual at the heafl of healthcare and ethics. Ethical Currents 1999;57:7-9.

9 The Bible. Luke 8:17; Hebrews 4:13.

10 Muramoto O. Bioethics of the refusal of blood by Jehovalo Witnesses: part 1. Should bioethical deliberation consider dissidents' views? fournal of Medical Ethics 1998;24:223-30.

11 Board of Ethical and Social Responsibility for Psycholog Memo to Deceptive and Indirect Methods of Persuasion and Contrat Committee. Washington: American Psychological Associatio 1987 May 11 .

12 Melton JG. The modern anti-cult movement in historic perspective. Santa Barbara, California: Institute for Study $\underline{\underline{\theta}}$ American Religion, 1995.

13 Ridley DT. Honoring Jehovah's Witnesses' advance directiv in emergencies. Academic Emergency Medicine 1998;5:824-35J

14 Stark R, Iannacone L. Why the Jehovah's Witnesses grow so rapidly: a theoretical application. fournal of Contemporary ReQ gion 1997;12:133-57.

15 Watch Tower Bible and Tract Society of Pennsylvania. Helpin people to draw close to Jehovah. The Watchtower 1999;14:9-1

16 Watch Tower Bible and Tract Society of Pennsylvania. Are you fulfilling your whole obligation to God? The Watchtowes 1999;22:18-23.

17 The Bible. Jude 21-23; Acts 20:26; 1 Corinthians 5:11-13; Re Corinthians $2: 6,7,14-17 ; 2$ Timothy $2: 16-18$.

18 The Bible. 1 Corinthians 5:11.

19 Watch Tower Bible and Tract Society of Pennsylvania. If a rele tive is disfellowshiped .... The Watchtower 1981;18:26-31.

20 Watch Tower Bible and Tract Society of Pennsylvania. Disciplife that can yield peaceable fruit. The Watchtower 1988;8:26-31.

21 Malyon D. Transfusion-free treatment of Jehovah's Witnesses respecting the autonomous patient's motives. Fournal of Medical Ethics 1998;24:376-81.

22 Eliade M, ed. Encyclopedia of religion. New York: Macmilla 1987.

23 The Bible. Psalm 32:5; 1 John 1:9.

24 The Bible. James 5:14-16; Proverbs 28:13; Galatians 6:1.

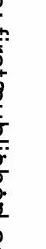

